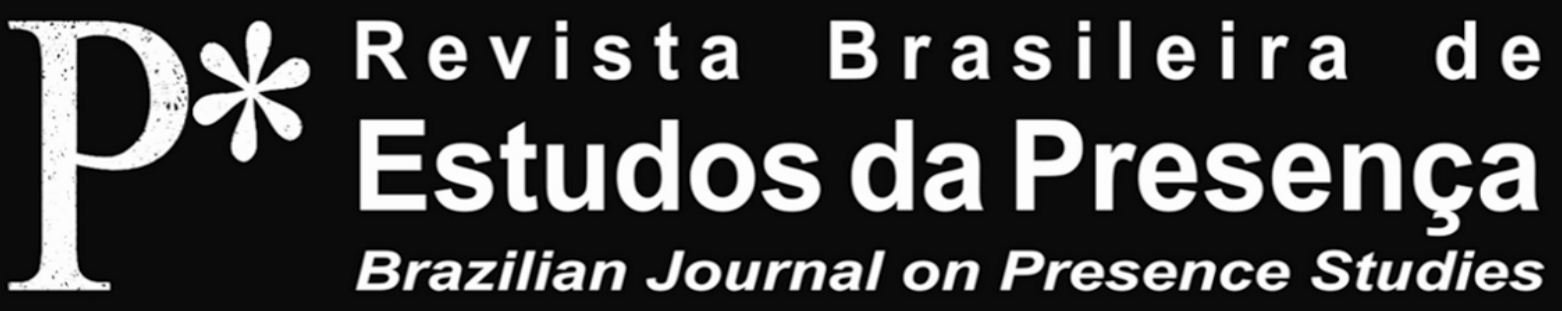

OTHER THEMES

E-ISSN 2237-2660

\title{
Irreverent Movements: Butoh tools for anthropological teaching and research
}

\author{
Lucrecia Raquel Greco, ${ }^{1,1}$ \\ 'Universidade Federal da Bahia - UFBA, Salvador/BA, Brazil \\ "Universidad de Buenos Aires - UBA, Buenos Aires, Argentina
}

ABSTRACT - Irreverent Movements: Butoh tools for anthropological teaching and research - This article explores how certain tools of Butoh and related techniques can become useful devices to sentipensar (think-feel) problematics addressed by anthropology. It first highlights how attention to corporeality and the presence of researchers and learning communities questions logocentric parameters of knowledge production and transmission. Then, based on experiences in teaching, performance and learning, we propose a few Butoh-inspired training devices that can be deployed to further explore topics related to notions of personhood, agency, time, memory, nature-culture and post-humanism, among others.

Keywords: Butoh. Anthropology of the Body. Research and Teaching. Ontologies. Performance Research.

RÉSUMÉ - Mouvements Irrévérencieux: instruments du Butoh pour l'enseignement et la recherché en anthropologie-On explore comment quelques outils du Butoh et de techniques similaires peuvent constituer des dispositifs bons à sentipenser des problématiques de l'anthropologie. On met l'accent sur la manière don't l'attention portée à la corporéité et la présence des chercheurs et des communautés de'appretisage alimente des investigations anthropologiques en s'opposant à des paramètres logocentriques. À partir d'expériences d'enseignement, de performance et d'apprentissage, on propose quelques dispositifs-entrainements spécifiques que l'on peut pratiquer. Ces dispositifs sont des outils qui permettent d'approfondir certaines thématiques telles que la personne, l'agence, le temps, la mémoire, la nature-culture et l'antropocentrisme, entre autres.

Mots-dés: Butoh. Anthropologie du Corps. Recherche et Enseignement. Ontologies. Recherche á travers la performance.

RESUMEN - Movimientos Irreverentes: elementos de Butoh para la enseñanza e investigación antropológicas - En este artículo se explora cómo algunas herramientas del Butoh y técnicas afines pueden constituirse en dispositivos buenos para sentipensar problemáticas abordadas por la antropología. Se destaca primero cómo la atención a la corporalidad y a la presencia de lxs investigadorxs y las comunidades de aprendizaje cuestiona parámetros logocéntricos de producción y transmisión de conocimiento. Luego, a partir de experiencias en docencia, performance y aprendizaje, se proponen algunos dispositivos-entrenamientos inspirados en el Butoh que pueden desplegarse para profundizar en tópicos relacionados a nociones de persona, agencia, tiempo, memoria, naturalezacultura y poshumanismo, entre otros.

Palabras dave: Butoh. Antropología del Cuerpo. Enseñanza e Investigación. Ontologías. Performanceinvestigación. 


\section{Introduction}

In this article, I present certain dialogues between elements of Butoh and other related techniques ${ }^{1}$ and some anthropologies, exploring how the tools of specific performance techniques can be used as useful devices to sentipensar $^{2}$ (think-feel) issues of anthropology and other social and human sciences. In this way, I explore various anthropological problems that Butoh and other similar performance arts can bring to the stage and I propose a few specific training-devices that we can traverse as researchers and learning communities to delve into ways of knowing that are attentive to our own corporealities and those of others (Csordas, 2011).

I believe that a sustained and expanded attention to corporeality, as proposed by Butoh and other systems of existence and performance, allows us to remake the academic habitus (Citro et al., 2016). As such, I would emphasize the potential of Butoh and other related arts and techniques to move towards modes of generating and transmitting anthropological knowledge that underline the embodied condition of our anthropological, humanistic, posthumanistic, and scientific imaginations in general. I believe that explorations in corporeality contribute to producing knowledge that fully recognizes the diverse forms of existence, thus challenging anthropocentric, ethnocentric and logocentric parameters. I also argue that dialogues between humanities and performing arts in general have the potential to increase the communicability of certain theoretical proposals (hooks, 2019) by broadening our academic ways of knowing. On the other hand, these reflections can also contribute to some practices and research in Butoh and performing arts by providing plural dialogues, from diverse traditions; andby systematizing, collectivizing and situating creative processes that often appear as individual or fragmented.

The reflections presented here came in particular from my collaborations and dialogues as a workshop coordinator of Butoh tools and other performative and somatic techniques, since 2014, which were fed in turn by my broader trajectory as an apprentice and performer of Butoh and other body techniques since 2000, as well as by my work as a researcher and instructor in the area of anthropology of the body and performance in conjunction with the Anthropology of the Body Team at Universidad de Bue- 
nos Aires since 2006 (Citro; Greco; Torres Agüero, 2019; Greco, 2017; 2019); and by further dialogues undertaken between performance and anthropology in recent years (Greco; Dagnino Ojeda, 2019). It is important to clarify that this paper is not an anthropological/sociological study of Butoh and its practice, but an exploration of tools based on it and other performance arts (and existence) for research and teaching in anthropology.

Therefore, it is an exploration from the complex in-definitions of performance studies-practices (Taylor, 2015; Turner, 1992) where I investigate how the practice of Butoh and other performative-existential arts can propitiate processes of reflexivity that constitute a means of producing anthropological knowledge. In this way, the proposals analyzed and presented here are based on experiences effectively carried out by me in different collectives.

In the first inhalation ${ }^{3}$ I will highlight certain advantages of the attention to corporeality, the presence and/or situationality of researchers for the development of research and teaching in anthropology and other humanities (and even humanimalities ${ }^{4}$ and sciences in general). Then, exhaling, I will explain the way in which devices based mainly on Butoh permit us to approach specific problems or theoretical currents. In this sense, I propose exercises in Butoh and related techniques accompanied by instances of embodied theoretical reflection. The exhalations will be done in three timesthemes: 1. notions of personhood and agencies; 2 . temporality and memory; and 3. nature-culture and post-humanisms. Finally, by expanding the air in and out of our bodies, I will present the conclusions in the final movement.

\section{Inhaling Theoretical Bases: embodied knowledge}

Several performative disciplines, as well as various human sciences and popular and militant knowledge systems converge to emphasize that we exist and know situationally and that mental processes are always embodied. Anthropology and other human - social - and post-human disciplines have highlighted the importance of considering the implications derived from the characteristics of researchers' presence in the production of knowledge, whether in fieldwork or other types of research. In order to highlight the way in which attention to corporeality can be an interesting tool for an- 
thropological inquiry, I will trace a brief and by no means exhaustive overview, highlighting the place that different theoretical positions afford to presence and situationality.

A number of authors highlight the importance of situationality by underscoring the geopolitical, historical and subjective trajectory and position of researchers. Donna Haraway (1995), from feminist criticism, remarks that there are no disembodied objectivities, since our scientific observations and knowledge are always situated and partial. It is precisely by acknowledging this situatedness that we can produce objectivities. Black feminism has also highlighted Black women's experience in the production of knowledge (Ribeiro, 2017; hooks, 2019). In addition, authors such as Frantz Fanon (2008) and Aimé Cesaire (2006) or Archie Mafeje (apud Borges et al., 2015) have also highlighted how their reflections emerge from their racial positions and experiences in diverse contexts. In this sense, taking both this situationality and diverse African existential proposals, Renato Nogueira (2011, p. 6), as a Black philosopher, proposes an "[...] afroperspectivist philosophy [...]" in which thought is always embodied, thus characterized by acting as a choreographic movement. Hence, from various positions, the importance of considering the places of speech (Ribeiro, 2017) and, it should be added, of sentipensamiento (thinking-feeling) in the production of academic knowledge has been underlined. Indigenous people, whites, women, the deaf, men, Blacks, immigrants, gypsies, mothers, mixed race, LGBT, among infinite intersectionalities (Crenshaw, 1989), constitute these critical situationalities.

From a position in which the body is perceived as a social phenomenon, the fruit of habitus ${ }^{5}$, Pierre Bourdieu (2003) proposes the idea of selfsocioanalysis as a way to objectify the objectifying subject. His colleague Wacquant experimented with observant participation, in which the sociologist appropriates "[...] in the practical skin of the cognitive, ethical, aesthetic and conative schemes put into daily operation by those who inhabit it [...]" (Wacquant, 2002, p. 11). Nick Crossley (1995), synthesizing the work of Bourdieu and Merleau-Ponty, proposes a carnal sociology that can integrate observation of the body with what the body does, understanding that we are always embodied subjects and that agency is always corporal. As such, the bodies of researchers and research subjects, always embedded in power 
relations, historically situated and limited, do not cease to constitute an "[...] active mode of being in the world [...]" (Crossley, 1996, p. 114).

From a phenomenological point of view and more specifically from the paradigm of embodiment, Thomas Csordas (2011, p. 83) considers that "[...] the embodied experience is the starting point for analyzing human participation in the cultural world" and proposes to take into account the "[...] somatic modes of attention [...]" (Csordas, 2011, p. 87), "[...] culturally elaborated modes of paying attention to and with the body in settings that include the embodied presence of others [...]". This attention is directed both to the researcher and to the intersubjective environment where he/she researches. Thus, corporealities are both subjects and objects in research. From the recognition of bodily agency, the Anthropology of the Body team at Universidad de Buenos Aires has been working on the design and experimentation of various methodological strategies to highlight the place of the body for those we research and teach (Citro et al., 2016).

Positions that do not focus on bodily experience or historical-political situationality also underline how researchers are affected by their presence in the field, recognizing the role of these affectations in the production of knowledge. In this way, some authors question research based exclusively on rational and utilitarian approaches, stressing the importance of "[...] granting epistemological status to these situations of involuntary and unintentional communication [...]" (Favret-Saada, 2005, p. 160). Although from these perspectives presence and affects are not defined as carnality ${ }^{6}$, it is believed that researchers in the field are affected in their entire being by the same forces that affect the native, thereby establishing particular relations with them (Goldman, 2003).

From my point of view or, following Csordas (lecture notes) ${ }^{7}$, a more carnal standpoint, those heterogeneous stances highlight corporealities, affections, socio-political and historical situations and present positions, thus enabling the entry into academic practice of carnal objectivities and objectivations, "carnal" reflexivities (Crossley, 1995, p. 49), embodied reflexivities (Rodriguez, 2009) or, at least, "affected" reflexivities, which allow us to delve into different sensory-perceptual and affective modes inherent to the whole cognitive process (Citro et al., 2016, p. 9). 
Considering these diverse genealogies, in order to read and understand the proposals that follow, I invite you to interpret corporeality as a space of agency in the production of knowledge. This recognition goes hand-inhand with the proposal, undertaken from performance studies, to acknowledge the productive role of experiences and performance in the social world (Boal, 1990; Schechner, 2000; Ligiero, 2012; Turner, 1982; 1992; Taylor, 2015). If by performing we produce world and agencies, we can also consider that we produce knowledge.

In the exercises I propose below, this agency of corporeality can be mobilized, however, to sentipensar (think-feel) diverse theoretical approaches that do not necessarily accentuate subjective agencies or even, as in the case of the biopolitical analyses I will address, diminish or deny them. As such, my intention is that these tools that I propose will allow us to sentipensar, from practices focused on somatic modes of attention, diverse positions in the issues-tensions that have dominated anthropology (nature, culture, sex, gender, race, individual, society, history, culture, ethnicity, the sacred, the profane, among others). I believe that, from experimentations in corporeality, we can embrace both approaches that consider mind and body as inseparable instances, as well as theories in which the body is in the mind and the mind is in the body (Lambeck, 2011). Likewise, these tools enable us to open polymathic dialogues (Burke, 2020) that will challenge biased assumptions from many strictly disciplinary areas of knowledge.

\section{Exhaling Devices: butokan-anthropological problems}

In this exhalation, I describe and propose devices based on Butoh and related techniques that invite us to take seriously ${ }^{8}$ the place of corporeality in our work as researchers and teachers of anthropology and other humanimal sciences.

I refer to devices such as discursive and non-discursive technological artifices that create the conditions to produce certain expected effects and not others (Fernández, 2007). In all cases, I propose that a variety of trainings are previously carried out in order to achieve extra-daily ${ }^{9}$ states of the body (training sessions in repetition, breathing, bioenergetic exercises, meditation, among others, according to space and time). 
I begin by considering that the configuration of aesthetic spaces (Boal, 1990), where extra-daily techniques and modes of perception are mobilized, permits the emergence of carnal reflexivities that allow us to understand aspects of our lives (individual and communal) that are lost in everyday life. The contrast of aesthetic space with the everyday experience of physical space (Boal, 1990) offers an opportunity to see aspects of the organization of lives that are denied, exacerbated, exaggerated, hidden or too explicit. Moreover, in the application of these and other devices of anthropological inquiry, it is essential to consider as much as possible the situationality and contexts in which we work, adapting language and proposals to each participating group and in each execution.

The devices I will present are based on techniques used in Butoh training and other performances, in dialogue with anthropological inquiries. Their implementation is not intended to prove theories, but to understand them, communicate them, and (senti)pensar (think-feel) them. In this way, it is a search for awareness so that certain problems and theoretical currents can be understood and communicated without depending exclusively on the journey through specific biographical/ethnographic experiences (such as passing through an illness, certain rituals, the experiences of gender, race, class, nation, maternity, disability, among others) or on a canonical academic education (such as the possibility of understanding certain texts only after years of reflections and readings in the academic sphere).

Next, I will describe some characteristics of Butoh in order to understand how it can be thought-practiced as a methodology of anthropological inquiry. Butoh is a performance art created in Japan after World War II. Its main mentors are Tatsumi Hijikata, choreographer and performer, and the dancer Kazuo Ohno, who inspired Hijikata and was directed by him. This art was formed between the legacy of World War II and the conflicts that arose between local traditions and practices coming from Europe and North America. During the 1970s, it began to be known and practiced in Europe, the United States, South America and Eastern countries; and, in Argentina, it began to gain strength in the 1990s and 2000s (Aschieri, 2015b). Its practice outside the context of creation has been diverse and dynamic, although many groups and masters seek to maintain some basic principles. One of the constitutive elements of Butoh is the questioning of individuality and will-consciousness, proposing itself as a performance method based 
on transforming oneself and not on doing (Greiner, 2015; Peretta, 2015; Aschieri, 2015b; Uno, 2018). In practice, a deautomatization is promoted, avoiding mechanical repetition, seeking to pay constant attention to emerging movements and sensations in order to generate an active bodily listening from which dance is generated. This proposal of a somatic mode of attention (Csordas, 2011) is based on an amplification of the attention to one's own body and the environment and seeks to focus on the multiple affections and trajectories of diverse origin that make up people. Hijikata sought the emptying and fragmentation of the body through a degradation of the subject in order to thereby achieve a fluid and polymorphous body that would offer radical resistance to the impositions of the dominant power structures, in a project of physical insurrection, an instrument of "[...] anthropological and political subversion" (Peretta, 2015, p. 11, 92, 103). For his part, Ohno proposed forms to annul individuality through love and gratitude, forms that would make it possible to expand physical consciousness beyond human sensibility, conceiving the body as a memory of the universe, integrating births, deaths, deformities, grotesqueries, eroticism, decrepitudes, among other affections, in a (meta) physical communion with the materiality of nature (Peretta, 2015). These questionings and deconstructions proposed by the practice of Butoh facilitate the creation of fruitful dialogues through the anthropological search to comprehend diverse ways and possibilities of existence (Ingold, 2011). At the same time, anthropological reflection can contribute to Butoh practice by observing situationalities in socio-environmental and historical perspectives and intensifying the reflexivity of the practice, building bridges between the experimentations of butokas and various collectives, emphasizing the possibility for producing movements, actions and states collectively, not limited to the individual or to artistic fields (Aschieri, 2015a, p. 3) ${ }^{10}$.

\section{Exhalation 1: notions of personhoodand agencies}

As I highlighted, the practice of Butoh explores notions of personhood by questioning the experience of the individual, encouraging performers to experience themselves in their becoming and multiplicity as beings who are permanently created in an open relationship with time and space, constantly being reborn, fragmenting and merging with other beings and materials. Butoh problematizes voluntaristic notions of agency by proposing "to be 
danced" (Aschieri, 2013, p. 254). This refers to a mode of practice detached from will and planning, in which movement happens from an attention focused on sensations and perceptions. These modalities are trained by focusing attention on breathing, different modes of perception (olfactory, gustatory, tactile, visual, auditory, synaesthetic), parts of the body, impulses, fatigue, among other possibilities. In phenomenological terms, it is about understanding agency beyond notions such as intention or interiority, enabling us to dance from multiple selfs ${ }^{11}$,also including the articulation between passivity and activity. For example, in training, you can focus attention on how you are breathing in order to observe the involuntary movement in that action, or experiment with dropping a part of the body, such as an arm, noticing how far the arm moves without exercising the will to move it, among infinite possibilities of inquiring into voluntary and involuntary movement ${ }^{12}$.

Bearing these training characteristics in mind, I therefore propose a few themes that may be worked on.

In order to investigate oppressive structures, norms or habits that make up the constitution of subjects, starting from notions such as habitus, disciplines and performativity, we can use an exercise present in various methods of performance composition, which consists of repeating movements mechanically until we find, through repetition, variations or outbursts, counterpoints, resistances, or oppositions. We can emphasize the way our routines, jobs, relationships or identities - such as race, gender, nation, ethnicity, sexualities -, compose us, find repetitive structures of movement linked to them and vanishing points. For example, we choose a gesture that makes us women, or a gesture linked to our everyday practices, and repeat it to reflect on the materiality of the body along with the materialization of regulatory norms (Butler, 2001). As a performer-apprentice, I went through this device along with companions in various trainings (physical theater, Butoh, theater of the oppressed, Agama fo) and, in general, the repetition of mechanical actions both makes the conditioning visible and promotes those outbursts in which the aforementioned subversions of the norm emerge as new, uncontrolled actions. On one occasion, during 2017, I used this exercise in an activity with public health agents in the Brazilian state of Bahia as part of a Public Health Education course. I proposed to make a machine out of the health center [public polyclinic]. When creating 
the machine, participants repeated the gestures of doctors walking haughtily with a cell phone in their hands, of patients begging to be seen, and of district agents in despair due to overwork. In this case, the repetition of the gestures led us to reflect on the corporal attitudes of the different actors and the hierarchies that are reproduced in the health center.

Another questioning of the notion of person - individual -, normative subject who can experiment through Butoh training, is the work with risk, discomfort and imbalance, often extolled in the training of this performance art. An exercise that I often use consists of proposing to transfer the weight to each space on the perimeter of the foot sole, or of the support point that we are using, and, if the position is based on the feet, to perform a triple flexion (in ankles, knees and hips) to experiment with changes in body axis, risking the chance of falling. From this experimentation, at some point of imbalance, one begins to run in different rhythms, including the most intense and accelerated, looking to get nowhere, running desperately without direction. On one of the occasions in which I proposed this device to a group of music students and researchers in performance and music, in a mixed workshop for the Theater of the Oppressed (TO) and Butoh that we coordinated with Armindo Pinto, curinga (joker, a multifunctional professional) from TO, during a meeting of ethnomusicology in Tuxtla, Chiapas, $2020^{13}$, a young music student noted that the proposal had made him more irreverent, so that he didn't care what others said. Another young person pointed out the liberating aspect of running with no direction, as this allows for actions that do not need to be explained. Another young person highlighted the liberating character of the device, afforded by the proposal to opt out of your balance, in contrast to a tango dance class he had taken a short time earlier in which a specific way of moving was proposed and had to be achieved. Subsequently, through TO exercises, we reflected on how those oppressions were generated, those that made everyday movements not be perceived as free. It should be noted that at no time during the workshop did I mention that a structure should be questioned, nor did I speak of freedom, but the proposal to explore uncontrolled and risky movements made us associate this experience with a level of movement that was freer of social mandates.

In order to sentipensar intercorporeality and intersubjectivity as constituent factors of the person, one can experiment with intercorporeal, non- 
verbal, preferably tactile and sonorous contacts. One device I have often worked with is based on breathing with others. First, I propose to focus on the breath itself, placing the hands on the abdomen, lumbar vertebrae, ribs, back and other areas of the thorax, to understand how breathing causes an expansion in all directions within the body. Participants then position themselves back-to-back with another person, sensing the others' breathing and their own until they create a joint rhythm. This last exercise highlights the importance of the embodied presence of others in the production of one's own breath. In Anthropology of the Body classes taught by me on the Graduate Program in Anthropology at Universidade Federal da Bahia in 2019, this exercise provoked discussions related both to the constitution of somatic modes of attention, by virtue of the proposal to be attentive to the presence of others with senses other than sight or hearing, as well as discussions about the oppressions that regulate our corporeality in the academic day-to-day, blocking the flow of our breathing and the perception of others present in the same space.

From Butoh and anthropological theater techniques, one can also sentipensar the various ways in which we are persons-individuals-collectives, exploring "[...] collective effervescences [...]", ritual experiences and other "[...] feelings of membership" (Scheper Hughes; Lock, 1987, p. 29). These states are present in rituals involving dance, music-movement, and altered states of consciousness, as well as in relational experiences of physical contact, e.g., when pregnant/breastfeeding/caregiver/baby or between lovers. Explorations through Butoh and other performances on these shared corporealities can take place with the aforementioned devices and through various proposals for shared and guided action in which the subjects enter into collective rhythms through breathing, movements, and sounds produced with the body or others, for example, by vibrating with one's own body near other people to generate collective dynamics. During a workshop given at the Agroecology Gathering of Rede dos Povos, in the Brazilian state of Bahia, I proposed exploring the potential for struggle in the body and, subsequently, finding rhythms and movements of collective struggle. In this way, the groups moved forward, improvising from a collectively created repertoire of struggle (Figure 1). These collective devices also allow us to explore experiences of membership based on more oppressive norms, such as those linked to waiting rooms, classrooms, public transportation, etc., instances in which 
membership is based on certain positions and bodily controls, as I recounted in the example of working with the health workers.

In relation to the various ways of being in and with the world and the limits of the person, one device is to focus attention on parts of the body as possibilities for entry or communication with the world and other persons and beings beyond the limit of the skin. We can concentrate attention on the porosity of the skin, body cavities, spaces between organs and bones, actions of absorption, suction, and nourishment. For example, to sentipensar experiences of possession, we can focus on the sacrum and its concavities as spaces for the entrance of the "saint" (Rodrigues, 2005, p. 50) ${ }^{14}$; or on the skull as an open space towards the celestial space; or on feet that extend like roots in the earth; among infinite possibilities. Through exercises of this type, we can enhance the reading of ethnographies that account for diverse ways of being in the world, or work on the notion of body-territory ${ }^{15}$ with different collectives.

\section{Exhalation 2: temporality and memories}

For Ohno, Butoh means wandering between the realm of the living and the dead, in a community of the past and potential memory of future lives (Peretta, 2015, p. 123; Fraleigh; Nakamura, 2006, p. 39). At the same time, according to Uno (2018, p. 38), for Hijikata, the Butoh approach is not about the practice of memory in the sense of an adult's recollection of childhood, but rather the perception of adults who are simultaneously children: everything is present and happening at the same time. Thus, these practical concepts of Butoh allow us to dialogue with notions of anthropology and human sciences that investigate the ways in which the past is sedimented in the body in a personal and collective way. On the other hand, the presence of the past in the present body allows us to question dual visions in which the past is either a fabulation at the service of the present or an external force that determines the future becoming (Rabelo, 2008); or to work on collective memories and cultural and decolonial criticism, exploring selective traditions and the ways in which disputing tradition means disputing the future (Williams, 1988).

The device with which I have worked to sentipensar notions of historicity, memory, selective memories and the various conceptions of time is 
based on the timeless walk of Butoh (a walk focused on slowness and on the path of the foot on the floor and whose objective is to take as much time as possible to traverse the space). In general, I propose to perform this walk inspired by the Aymara aphorism qhipnayra uñtasis sarnaqapxañani, often quoted by Silvia Rivera Cusicanqui (2010; 2015), which proposes a way of living by looking at the past to walk through the present and the future, in an active and cyclical recreation of memory ${ }^{16}$. The walking proposal consists of observing the past in front of us, constructing in each step a future that we carry on our backs. The load of the future is built by the selection we make when exploring the past. To focus the attention on the back of the body, I generally propose previous training exercises involving the back and sides of the body to produce a decentering of the frontal part of the body and the primacy of sight. Various exercises such as the back contact breathing help us to become aware of the muscular presence of the back or the circularity of the internal organs, such as the lungs. This can also be done by emphasizing the spherical presence of the body, which, like a tree, has no front or back, and expands upwards through the branches and downwards through the roots in an infinite way.

This device of walking and reflecting on the experience of temporality can also be contemplated from other narratives and experiences besides the Aymara. For example, from the afro-perspectivist philosophy inspired by Bantu philosophies, Nogueira emphasizes that our ancestors live in the bowels of the earth and therefore, every time we step on the earth we know that with our steps we give meaning to the present life. The afroperspectivist future is also found in the past, in the sense of a future immanent to the past ${ }^{17}$. In this case, one could perform the walk focusing the attention on the feet that step on a land populated by ancestors and propose to create the present and the future with the feet, in a "choreographic invention" (Nogueira 2011, p. 14).

The core of the device consists in targeting the embodied memory, the sedimentation of the past in the body and the future that is constructed from that position. Therefore, phenomenological theories, diverse indigenous or afro-perspectivist philosophies, ethnographic readings, ways in which societies remember (Connerton, 1989), colonialities (Dussel, 2000; Lander, 2005; Sousa Santos, 2010), and biographies can be worked on as well as accompanying collective processes of organization, among other pos- 
sible timeless paths. It is interesting in each case to select the sounds or music that accompany the process, as these create a landscape that can define in more specific ways the memories to be addressed. Likewise, it is worthwhile, depending on the objectives of the inquiry, not to indicate or suggest the geopolitical or historical contents of the landscapes in the proposal: in general, I propose to walk through a past that we are creating, which can be biographical, familial, ancestral, environmental, among an infinite number of possibilities.

Most of the workshop participants, in the various editions, reported having experienced their corporealities in unusual ways, becoming more sensitized to the perception of time and space. For some people, especially those practicing Afro-Brazilian and Christian religions, feelings such as these were part of known experiences of possession or connection with entities, while for others it was a novel experience, which, in many cases, brought an awareness of belonging to a collective and/or a genealogy. For example, on one occasion when I carried out this exercise in the city of Salta, northern Argentina, a young theater student, a mestiza, told me, crying, that she had felt for the first time that her ancestors were indigenous. She recounted that she had never thought about it, but that, as she walked and explored further, she had discovered the importance of her indigenous ancestry. It is important to note that Salta is a province with a large indigenous and mixed-race population, a territory where there are profound inequalities and stigmas that weigh on the indigenous peoples. Furthermore, in an intensive Butoh workshop I gave in Quito, Ecuador, the participants commented that the past they had worked on was related to indigenous ancestry. In neither case did I verbally suggest that they focus on the indigenous past, but in both cases I played Indo-American music, which may have induced the associations and experiences of the participants.

On another occasion, after participating in a Butoh tools workshop I coordinated at the Encontro Sem Fronteiras de Teatro do Oprimido (Theater of the Oppressed Gathering Without Borders) in September 2017 in Lauro de Freitas, Bahia, Brazil, Isis, then a member of the Grupo de Teatro do Oprimido Pé de Poeta, described her experience in a poem largely based on words I spoke during the workshop's orientation:

Futuro nas costas, presente. Em tua frente passado carregado, numa mala de memórias. recordaçóes do corpo no espaço, por todo canto que passo deixo e absorvo 
rastros de alguém que passou por aqui, de quem permanece aqui, rastros de mim. Assim, meu corpo presente, seu corpo presente sei disto, sem que haja toque. Fazemos o mesmo movimento, num mesmo tempo e laço. desafiando a lei de que: dois corpos não ocupam o mesmo espaço (Isis, Poema, Grupo de Teatro do Oprimido Pé de Poeta, Bahia, Brasil $)^{18}$.

As Lepecki (2005) points out, dance, instead of passing through time and space, generates time and space. In this aesthetic space, simultaneous and different from physical space (Boal, 1990), Isis highlighted the sensation of dance with diverse times and links that she had been able to experience through the proposal.

\section{Exhalation 3: agencies, naturesand posthumanisms}

From the practice of Butoh, human existence is understood as being rooted in the organic, in nature and not above it (Peretta, 2015). In fact, one of the sources of Hijikata's Butoh was the somatic intimacy with nature (Fraleigh; Nakamura, 2006). As such, the practice of Butoh is a possible interlocutor in the questioning of anthropocentrism, as it makes it possible to undo hegemonic images of humanity built on the basis of bipedalism, verticality, the importance of the hands, visuality, reason, culture, society, history and the renunciation of belonging to the world in which we find ourselves (Kohn, 2013; Ingold, 2012). Butoh also encourages the realization that we are in a shared world of companion species (Haraway 2008), and seeks to understand the semiotics of the living world (Kohn, 2013). In tune with post-humanist, animist, decolonial, ecofeminist ${ }^{19}$ and well-living currents, Butoh invites us to "[...] recognize the fact that seeing, representing and perhaps knowing, even thinking, are not exclusively human affairs" (Kohn, 2013, p. 1) and that the world is animated and enchanted (Hall, 2011; Kohn, 2013; Holbraad; Pedersen 2017; Fernández Guerrero, 2010; Stengers, 2017) ${ }^{20}$.

In practice, these inquiries into human and non-human agencies and relationships are conducted using the various techniques to be danced, such as those mentioned in the first section. Butoh is a tool to decentralize the anthropocentric experience of the world by inviting us to non-erect body positions and to look outward and inward with half-open eyes. Likewise, a deconstruction of utilitarian motricity is proposed, focusing on the "[...] nascent awkwardness [...]", with the goal of moving as a fetus (Quignard, 
2017, p. 62). This quest deconstructs bipedal walking with its vertical and forward orientation, implying a questioning of linear time and space experiences. As the master teacher Yael Karavan stressed in a workshop she gave in Salvador de Bahia in 2019, Butoh is a dance that does not begin standing up. The proposal of butoka bodily presence shows us that the emphasis on bipedalism and the objective gaze is only one possible position in the world ${ }^{21}$; and it promotes a search to make present subcortical experiences that enable us to apprehend the world in its condition of force field that affects us and is made present in our body in the form of sensations (Roelnik, 2013). In dance, we seek to understand and relate to/experience nonhuman entities (internal and external) as persons or egos, with their own perspective and ability to communicate, without attributing anthropomorphism to them. From post humanist thought, we can comprehend that the agency of such entities is not to be described, in Latour's terms (1988 apud Holbraad; Pedersen, 2017, p. 206), as the realization of a human intention, but as an ownership of relational networks. For example, in the creation of a performance in collaboration with a midwife stage director, we worked, by means of my own gestating body, on the linking of beings during gestation and childbirth, inquiring into the existence-agency of the placenta as an ephemeral organ that is born to gestate and dies when the fetus is born (Greco; Dagnino Ojeda, 2019). In this performance (Figure 2), we take advantage of the work of bodily awareness through the physiological processes of pregnancy in order to give intelligibility to the action of hormones, ephemeral organs such as the placenta, the uterus and fetuses. 


\section{Revista Brasileira de Estudos da Presenca Brazillan Journal on Presence Studies}

Figure 1 - Lucrecia Greco (performer) in Experimentation Work. Fetus. Serra Grande, Bahia, Brazil, 2018. Still frame from video filmed by Martino Piccini, Antonio Ternura and Sergio Gidoux. Concept: Paulina Dagnino Ojeda and Lucrecia Greco. Source: Author's personal archive.

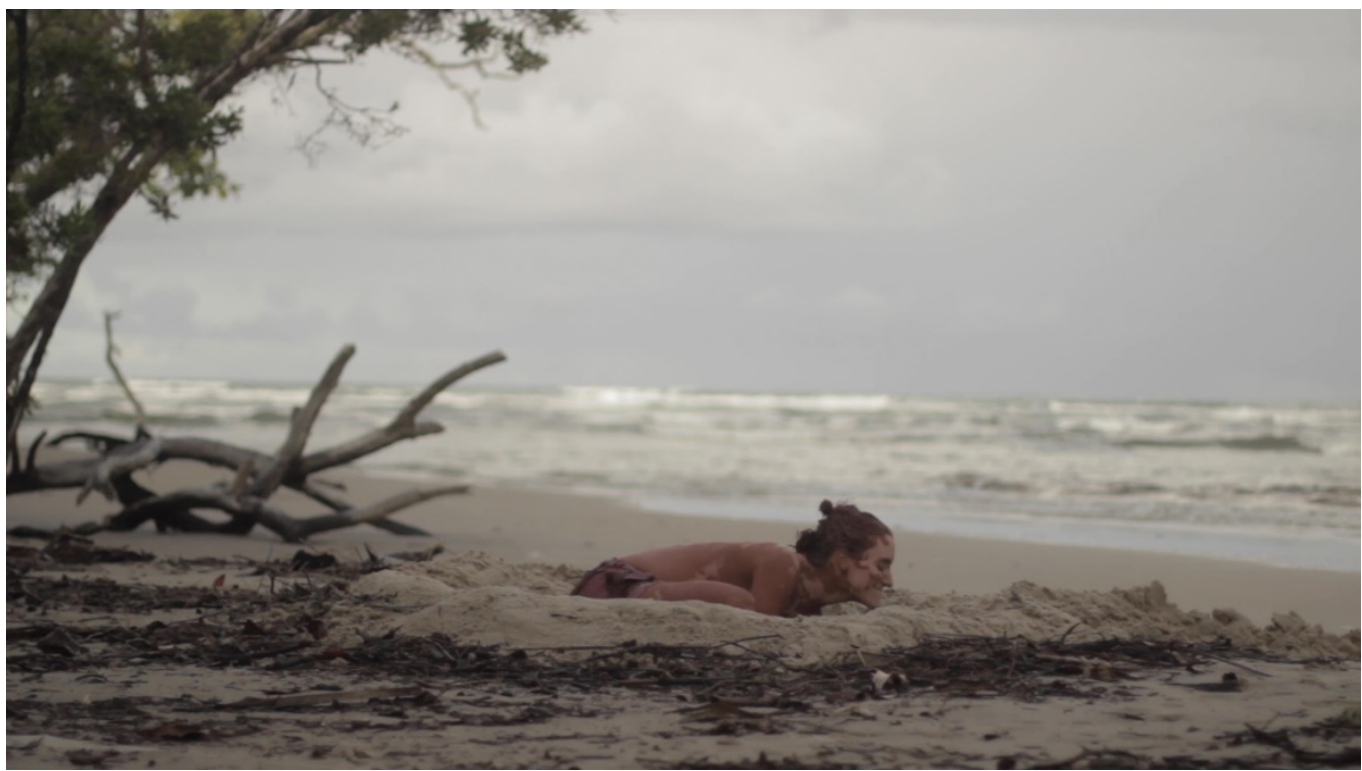

Figure 2 - Lucrecia Greco (performer) in Experimentation Work.Placenta. Serra Grande, Bahia, Brazil, 2018. Still frame from the video Compañera Visceral filmed by Antonio Ternura and Sergio Gidoux. Concept: Paulina Dagnino Ojeda and Lucrecia Greco. Source: Pluriverso Germinal2.

To explore how verticality, bipedalism and consciousness constitute only a part of the world experience, in some practices I propose devices to decenter the vertical axis and the forward gaze, walking with the legs bent and the torso inclined. I also seek to deconstruct the primacy of visuality, by considering sight as situated in the body, being as carnal and subjective as any other sense ${ }^{23}$. The eye can be experienced as a sphere that looks to all sides, even inward. Also, the gaze can be expanded from the eye to the whole body by means of focusing and unfocusing exercises and perception of the whole body surface. Another interesting element is to concentrate on the connection of head and body by becoming aware of the spine's structure. One possibility that I have tried out in classes I have taken, performances I have given and workshops I have conducted is to draw attention to the space-trajectory of the spine between the sacrum and the tongue. To this end, I find it useful to mentally repeat a mantra from Rosana Devesa, an expert transmitter of the Fedora Aberastaury method: marrow to tongue, aiming for these words to resonate in the space of the body that we name. Concentration on this path, which coincides with that of the cerebrospinal 
fluid (Bainbridge Cohen, 2015), makes us tend to relax and focus attention on the relationship between coccyx, axis and head. Spinal mobility exercises can also be performed, by vibration or voluntary movement, in which cervical movement is included and emphasized. The exercise from medulla to tongue, as well as those in which we focus, for example, on thinking about the continuity of our sacrum as an animal tail, or different approaches to animal bodies, allow us to inquire into the permeable limits of the definition of humanity and rethink the way we typify what is human, questioning why attributes such as bipedalism and the gaze on the world are selected to characterize us (Haraway, 2008; Ingold, 2012).

On another occasion, I worked on this device with the Grupo de Teatro del Oprimido Pé de Poeta, placing emphasis on the sensation of being like a reptile, defocusing us from the brain (Figure 2). One workshop par-ticipant, an evangelical practitioner, expressed her fear of not being able to re-turn to reality if she followed my words and said that, for this reason, she had stopped following my proposal. Another young woman, also an evan-gelical, believed that the method was based on hypnosis and mind control and thought that the music (ethnic and experimental music) resembled songs used to access altered mental states. Meanwhile, her brother, also an evangelical, decided to withdraw as soon as I proposed the first hip and sa-cral movements ${ }^{24}$. These discussions provided an opportunity to think to-gether about how a part of our experience was being cut out of our lives, forcing us to think with our heads all the time.

Also on this and other occasions when I held this workshop, we were able to reflect on anthropocentrism and human predation in the world. The training of attention to the spine and the work with extensions allow us to explore the proximity of humanity to other species, finding analogies, antagonisms and other relationships. Understanding ourselves "[...] submerged on an equal ontological footing, in an ocean of materials [...]" with things (Ingold, 2007, p. 7) makes visible the conflicting and harmful imprints of humanity on the world (Haraway, 2016, Latour, 2017). As such, the practice of Butoh highlights the historical experience in which a part of humanity is provoking disconnection and destruction of the world, of other beings and other human beings (Haraway, 2019). On one particular occasion, along with Fernando Alves and Armindo Pinto, both members of the Grupo de Teatro do Oprimido Pé de Poeta, we used this marrow to the 
tongue training at the Congress of Political Ecology, Universidade Federal da Bahia, Salvador de Bahia, 2019. In this case, in collaboration with artists and activists, we continued the work by experimenting with qualities of movement inspired by the elements recognized by Yoruba religiosity (water, fire, air, earth and metal) and ended up building a machine from the industrial and pre-industrial world. The final exercise heightened our awareness by allowing us to feel the oppression that the elements suffered in the industrial world (the pre-industrial Yoruba metal became, for example, an extremely oppressive element, turning into a machine, while the air, fire, earth and water became sick). Thus, through corporal work and subsequent reflection, we investigated both our experience in the world and our destructive and dissociative agency with respect to it.

\section{Final Movements}

Studying diverse somatic modes of attention in our own corporealities as researchers, teachers and learners can lead us to raise new questions and approaches. At the same time, the embodiment of body languages in teaching and research is a tool to increase the communicability of scientific endeavors. Butoka modes of bodily attention can contribute to our epistemologies by helping us to understand ourselves situated and partial as we interact, fragment and merge, immersed in the world, with other subjects of knowledge.

In turn, anthropological reflections are interesting tools to collectivize the processes of performative research, also increasing the critical potential. Therefore, the objectification of a situated and context-centered thinking can contribute to the practice of Butohs and performances in new spaces, co-constructing realities with diverse collectives.

These dialogues also question the limits of academic and nonacademic knowledge, enriching our ways of sentipensar (thinking-feeling) and acting.

Throughout the text, I have described some examples of work on the notion of person, memory, humanity and environment in various fields, proposals that can be further developed and expanded into other topics. With different publics, the devices would make it possible to approach complex problems from critical perspectives incorporated in the work. 
In academic and extra-academic environments, Butoh and the reflection on its practice allow us to think and act out life projects, enabling the emergence of alternative epistemes-experiences in which we conceive ourselves in relationships, affected by other beings, human and non-human, and affecting them. The aesthetic space we generate in dance can also become a micropolitical space (Greco, 2017; 2020) since, situated simultaneously in our physical worlds, we are training other ways of being in, communicating with and perceiving the world.

In this way, we are invited to walk in a space that is not a predetermined territory, but a result of the movements in which, as humans, we make ourselves with each step or each dance. It is up to us to situate ourselves in this space-time and to design our projects collectively and situationally.

\section{Notes}

1 I refer to butoh and related trainings in the fields in which I was trained. In Argentina, most of the teachers are influenced by Theatrical Anthropology or by various oriental martial arts, as well as by Grotowski's theater, spheres from which they seek to extract universal technical corporal principles of stage presence (Aschieri, 2015b; Barba, 2017). Teachers and performers also incorporate elements of bioenergetics, physical theater, yoga, fedora, taichi, chi kung, eutonia, feldenkrais, axys syllabus, Body Mind Centering, Afro-Brazilian performance techniques, among other techniques that have in common a search for embodied consciousness and thought.

2 Following the proposal of Orlando Fals Borda and Eduardo Galeano, I prefer sentipensar to emphasize a thinking that combines reason and love, body and heart (Galeano, in Moncayo, 2009) in a way that is committed to the reality in which it is immersed. In the current context, where the production of knowledge is under attack by some national governments, such as that of Brazil, it is important to point out that contesting logocentrism does not imply advocating anti-rationalism, but simply understanding the limits of logocentric, and also anthropocentric, patriarchal, racialized and classist methods and premises prevalent in academic activities.

3 I use the metaphor of inspiration both in the sense of stimulus and in the sense of breathing, as a proposal to embody this reading. 
4 I refer to feminist author Aler's (2010) proposal to consider the biological, social and cultural continuity between humans and animals. This idea was also worked on in the canonical academic sphere in the post-human sciences (see, for example, Taylor; Signal, 2011).

5 Bourdieu's notion of habitus was based on a reworking of phenomenological currents (Crossley, 2001). Crossley (1995, p. 56) believes that Merleau-Ponty's phenomenology can be taken as a carnal version of Bourdieu's habitus. For Merleau-Ponty, the subject-body knows the world in a practical, existential way, independent of intellect or reflection; thus, the relationship of the subject with the world is not of the order of the I think, but of the I can, as in the practical meaning postulated by Bourdieu.

6 Affections, in Deleuze's logic, have to do with a conception of the body as "[...] a bundle of affections [...]" to which behaviors, abilities and desires are associated (Macedo, 2013, p. 185-186).

7 Notes taken during an intensive seminar given by the author at the Facultad de Filosofía y Letras of the Universidad de Buenos Aires in 2012.

8 I paraphrase the famous perspectivist proposal of taking seriously native discourses (See Viveiros de Castro, 2002).

9 Everyday techniques "[...] are not conscious, they are culturally determined and based on the law of least effort, they are useful within the framework of the social condition and the occupation of individuals [...], while extra-daily techniques do not respect these habitual conditioning factors for the use of the body, they are a waste of energy and are linked to contexts of representation [...]" (Islas, 1995, p. 198).

${ }^{10}$ In this sense, I consider the proposal of Boal (1994), who, from the Theater of the Oppressed, suggests that, after performing scenes or trainings, emotions should be rationalized. Although his presentation reproduces dualisms, his proposal for the integration of experiences through attention to corporeality, emotionality and expressiveness for deeper processes of reflection and reflexivity is interesting.

11 Scheper Hughes and Lock (1987) point out that, in various societies, the individual is composed of multiple selfs, manifesting in possession practices and altered states of consciousness without these states being pathologized. Rabelo (2008) also highlights the experience of multiple agencies in candomblé possession. Butoh enables these inquiries in its proposal to break away from the self-contained experience of individuality. 
12 It is worth citing as an example Schechner's characterization (in Ligiero 2012) of rasa aesthetics, in which the brain located in the belly (the enteric nervous system) plays a fundamental role.

13 The II LatCar 2020 Symposium, Tiempo, Identidad y Memoria, washeld in Tuxtla in March 2020.

14 The author states that, for some candomble practitioners, the saint enters through the sacrum. She also cites the example of a Chinese martial arts' master who refers to the sacral area as the place of entry of eight energies through its orifices.

15 For ethnographies, we can cite several examples, such as studies on lowlands that analyze body-world experiences (Citro, 2008), native hematologies (Belaunde, 2006), among other multiple ethnographies. Similarly, it is worth considering these methodologies to work on corporal cartographies from the perspective of the body-territory relationship, as several feminist and ecofeminist collectives have been doing (Cruz Hernández, 2020).

16 Nayra means eye and also past; it is a concept of time with which is expressed the idea that, both in time and in space, the future is behind our backs, while the past is in front of our eyes.

${ }^{17}$ In Bantu traditions, the community has three dimensions: the ancestors, the living and the unborn. Creativity consists in leaving what was inherited from the ancestors more beautiful, comfortable and functioning properly for future generations (Nogueira, 2012).

18 Future on my back, present. In front of you, the past carried in a suitcase of memories. Memories of the body in space, everywhere I go I leave and absorb traces of someone who has passed by here, who remains here, traces of me. Thus, my body present, your body present I know this, without any touch. We make the same movement, in the same time and loop. defying the law that: two bodies do not occupy the same space.

19 Ecofeminist sciences seek "[...] to restore the dignity and spirituality of the object of study [...]", not by being above what is being investigated, but in front of it, knowing by means of "[...] an empathetic vision, in solidarity with all living things, which discards any attempt at destructive appropriation" (Fernández Guerrero, 2010, p. 1-3). 
20 Certainly these proposals are not only found in Butoh. Quintero Rivera (2009) highlights that mulatto dances activate polytheisticanimisms as central forms of an ecological humanism.

21 The artist Edu $\mathrm{O}$ offers an interesting critique of bipedalism: "Bipedalism understood not only as locomotion on two limbs, but also as a socio-political structure determined by the world perspective oriented only by the demands of those who do not have any disability and who consider all those who are not part of their group as disabled, inept and inferior. Bipedalism acts in relation to all types of disability, from physical, to visual, auditory, and intellectual, etc." Available at: <https://www.correio24horas.com.br/noticia/nid/vocesbipedes-me-cansam/>. Consulted on: 18 Feb. 2021. ["Bipedia compreendida não apenas pela locomoção em dois membros, mas como estrutura sóciopolítica determinada pela perspectiva de mundo pautada apenas pelas demandas de quem não possui deficiência, considerando todos aqueles que não fazem parte do seu grupo como incapazes, inaptos e inferiores. A Bipedia age na relação com todos os tipos de deficiência, desde a física até a visual, auditiva, intelectual, etc."].

22 Available at: <https://vimeo.com/user34599754/review/431174382/0b4c381be1>. Consulted on: 18 Feb. 2021.

23 As Ingold (2012) proposes, vision is presented as an objectifying sense, while, for example, hearing and the experience of sound seem to be the same thing, permeating the whole being. Accordingly, he points out, vision could act in a similar way, since we are immersed in visual space, a space of light (Ingold, 2011).

${ }^{24}$ It is worth highlighting this representation by the evangelical participants on how corporal work could alter the mind and lead tolosing control over it, a theme that is repeated in the various spaces of work with artistic performances in which I have participated. For example, when I worked among capoeiristas from Santa Maria (southern Brazil), they recounted various discussions they had with evangelicals in order to show them that what they were doing was not religion or any kind of mind control (Greco, 2017). Also within the framework of a collaborative research involving women from Barrio 31 (Buenos Aires, Argentina), on one occasion I had to explain to the evangelical husband of one of them that yoga was not a system for the induction of feelings and thoughts (Greco, 2017). 


\section{Revista Brasileira de Estudos da Presença Brazilian Journal on Presence Studies}

\section{References}

ALER, Isabel. Los modos de ser madre. Buenos Aires: Fanzine Serie Cuidadania, 2010 .

ASCHIERI, Patricia. Subjetividad en Movimiento: reapropiaciones de la danza Butoh en Argentina. Tesis (Doctorado en Antropología) - Facultad de Filosofía y Letras, Universidad de Buenos Aires, Buenos Aires, 2013.

ASCHIERI, Patricia. El Butoh en Argentina. Ensayo para definir lo inclasificable: los cuerpos de la danza Butoh. El apuntador, Quito, v. 61, p. 1-5, 2015 a.

ASCHIERI, Patricia. Maquillar los cuerpos / Transmutar en movimiento: Reflexiones acerca de las reelaboraciones de la danza Butoh y sus máscaras. Cuadernos de Música, Artes Visuales y Artes Escénicas, Bogotá, v. 10 n. 1, p. 95-113, 2015b.

BAINBRIDGE COHEN, Bonnie. Sentir, perceber e agir. São Paulo: SESC, 2015.

BARBA, Eugenio. La luna surge del Ganges: mi viaje a través de las técnicas de actuación asiáticas. Buenos Aires: Ediciones del Camino, 2017.

BELAUNDE, Luisa Elvira. A força dos pensamentos, o fedor do sangue. Hematologia e gênero na Amazônia. Revista de Antropologia, São Paulo, v. 49, n. 1, p. 205-243, 2006.

BOAL, Augusto. Méthode Boal de théâtre et de Thérapie: L'arc en ciel du désir. Paris: Ramsay, 1990.

BOAL, Augusto. Jeux pour acteurs et non acteurs: pratique du Théatre de l'opprimé. Paris: la découverte, 1994.

BORGES, Antonádia et al. Pós-Antropologia as críticas de Archie Mafeje ao conceito de alteridade e sua proposta de uma ontologia combativa. Sociedade e Estado, Brasília, v. 30, n. 2, p. 347-369, 2015.

BOURDIEU, Pierre. Creencia artística y bienes simbólicos: elementos para una sociología de la cultura. Córdoba; Buenos Aires: Aurelia Rivera, 2003.

BURKE, Peter. The Polymath: a cultural history from Leonardo da Vinci to Susan Sontag. New Haven; London: Yale University Press, 2020.

BUTLER, Judith. Corpos que pesam. Sobre os limites discursivos do sexo. In: LOURO LOPES Guacira (org.). O corpo educado, Pedagogias da sexualidade.

2. ed. Belo Horizonte: Autênticos, 2001. P. 153-172. 
CESAIRE, Aimé. Discurso sobre la negritud. Negritud, etnicidad y culturas afroamericanas. In: CESAIRE, Aimé. Discurso sobre el colonialismo. Madrid: Akal, 2006. P. 85-92.

CITRO, Silvia et al. Indagaciones colectivas de y desde los cuerpos. In: Encuentro Latinoamericano de Metodología en Ciencias Sociales, 5., Mendoza, 2016. Actas... Mendoza: Facultad de Ciencias Políticas y Sociales; UNCuyo, 2016. P. $1-23$.

CITRO, Silvia. Creando una mujer. Ritual de iniciación femenina y matriz simbólica de los géneros entre los toba takshik. In: HIRSCH, Silvia (comp.). Mujeres Indígenas en la Argentina. Cuerpo, trabajo y poder. Buenos Aires: Biblos; Culturalia, 2008. P. 1-32.

CITRO, Silvia; GRECO, Lucrecia; TORRES AGÜERO, Soledad. Las corporalidades de la etnografía: de la participación observante a la performanceinvestigación colaborativa. In: KATZER, Leticia; CHIAVAZZA, Horacio. Perspectivas etnográficas contemporáneas en Argentina. Mendoza: EDIFYL, 2019. P. 103-171.

CONNERTON, Paul. How societies remember. Cambridge: Cambrigde University press, 1989.

CRENSHAW, Kimberle. Demarginalizing the Intersection of Race and Sex. Chicago: University of Chicago Legal Forum, 1989.

CROSSLEY, Nick. Merleau-Ponty, the elusive body and carnal sociology. Body \& Society, Thousand Oaks, v. 43, n. 1, p. 43-63, 1995.

CROSSLEY, Nick. Body subject/Body power: agency, inscription and control in Foucault and Merleau-Ponty. Body \& Society, Thousand Oaks, v. 2, n. 2, p. 99116, 1996.

CROSSLEY, Nick. The phenomenological habitus and its construction. Theory and Society, Dordrecht, v. 30, n. 1, p. 81-120, feb., 2001.

CRUZ HERNÁNDEZ, Delmy Tania. Mujeres, cuerpo y territorios: entre la defensa y la desposesión. In: CRUZ HERNÁNDEZ, Delmy Tania; BAYÓN JIMÉNEZ, Manuel (comp.). Cuerpos territorios y feminismos: compilación latino-americana de teorías, metodologías y prácticas políticas. Quito: Abya Yala; Bajo Tierra y Libertad Bajo Palabra, 2020. P. 45-62.

CSORDAS, Thomas. Modos somáticos de atención. In: CITRO, Silvia (coord.). Cuerpos plurales: antropología de y desde los cuerpos. Buenos Aires: Biblos, 2011. P. 83-104. 
DUSSEL, Enrique. Europa, modernidad y eurocentrismo. In: LANDER, Edgardo (comp.). La colonialidad del saber: Eurocentrismo y ciencias sociales. Perspectivas latinoamericanas. Buenos Aires: Consejo Latinoamericano de Ciencias Sociales, 2000. P. 41-53.

FANON, Frantz. Pele negra, máscaras brancas. Salvador: Editora da Universidade Federal da Bahia, 2008.

FAVRET-SAADA, Jeanne. Ser afetado. Tradução de Paula Siqueira. Cadernos de campo, São Paulo, v. 13, n. 13, p. 155-162, 2005.

FERNÁNDEZ GUERRERO, Olaya. Cuerpo, espacio y libertad en el ecofeminismo. Nómadas - Revista crítica de ciencias sociales y jurídicas, Roma, v. 27, n. 3, p. 243-256, 2010.

FERNÁNDEZ, Ana María. Las lógicas colectivas. Imaginarios, cuerpos y multiplicidades. Buenos Aires: Biblos, 2007.

FRALEIGH, Sondra; NAKAMURA, Tamah. Hijikata Tatsumi and Ohno Kazuo. Londres: Routledge, 2006.

GOLDMAN, Marcio. Os tambores dos mortos e os tambores dos vivos. Etnografia, antropologia e política em Ilhéus, Bahia. Revista de Antropologia, São Paulo, v. 46, n. 2, p. 445-476, 2003.

GRECO, Lucrecia. Descubrir cosas que una ni sabe que tiene. Micropolíticas de una experiencia de trabajo corporal con mujeres en El Barrio 31, Caba. In: CASTRO; Ana Lúcia de; LANDA, Maria Inés (org.). Corpos, poderes e processos de subjetivaçáo: discursos e práticas na cultura contemporânea. São Paulo: Cultura Académica Editora, 2017. P. 187-210.

GRECO, Lucrecia. Esa cuestión de que el negro se muestre: Performance y raza en dos proyectos sociales de Brasil y Argentina. In: MATTEI, Andrea Díaz (ed.). La negritud y su poética. Prácticas artísticas y miradas críticas contemporáneas en Latinoamérica y España. Montevideo; Sevilla: BMR Cultural; Publicaciones Enredars, 2019. P. 255-276.

GRECO, Lucrecia. A lição é mais para os capitalistas do que para nós: Micropolíticas de la Capoeira de Rua para no acomodarse en la pandemia. Revista Labrinto, Porto Velho, a. 20, v. 33, p. 10-24, 2020.

GRECO, Lucrecia; DAGNINO OJEDA, Paulina. Arte gestante-maternidades insurrectas: una narrativa del cuerpo gestante desde el Butoh y los cuidados. Revista Sociopoetica, Campo Grande, v. 1, n. 21, p. 187-199, 2019. 
GREINER, Christine. Leituras do corpo no Japáo e suas diásporas cognitivas. São Paulo: n-1 Edições, 2015.

HALL, Mathew. Plants as persons: a philosophical botany. New York: State University of New York, 2011.

HARAWAY, Donna. Saberes localizados: a questão da ciência para o feminismo e o privilégio da perspectiva parcial. Cadernos Pagu, Campinas, v. 1, n. 5, p. 7-41, 1995.

HARAWAY, Donna. When species meet. Minneapolis: University of Minessota Press, 2008.

HARAWAY, Donna. Clima Com Cultura Científica - pesquisa, jornalismo e arte, Buenos Aires, a. 3, v. 1, p. 139-146, 2016. Disponible en: <http://revistaleca.org/journal/index.php/RLECA/article/view/53/0>. Acceso en: 18 feb. 2021.

HARAWAY, Donna. Seguir con el problema: generar parentesco en el Tchuluceno. Bilbao: Consonni, 2019.

HOLBRAAD, Martin; PEDERSEN, Morten Axel. The ontological turn: an anthropological exposition. Cambridge: Cambrige University Press, 2017.

hooks, bell. La teoría como práctica liberadora. Nómadas - Revista crítica de ciencias sociales y jurídicas, Roma, n. 50, p. 123-135, 2019.

INGOLD, Tim. Materials against materiality. Archaeological Dialogues, Cambridge, v. 14, n. 1, p. 1-16, 2007.

INGOLD, Tim. Estar vivo: ensaios sobre movimento, conhecimento e descrição. Rio de Janeiro: Vozes, 2011.

INGOLD, Tim. Ambientes para la vida: conversaciones sobre humanidad, conocimiento y antropología. Montevideo: Ediciones Trilce, 2012.

ISLAS, Hilda. Tecnologías corporales: danza, cuerpo e historia. México: Instituto Nacional de Bellas Artes, 1995.

KOHN, Eduardo. How forests think: toward an anthropology beyond the human. Berkeley; Los Angeles: University of California Press, 2013.

LAMBECK, Michael. Cuerpo y mente en la mente, cuerpo y mente en el cuerpo. Algunas intervenciones antropológicas de una larga conversación. In: CITRO, Silvia (comp.). Cuerpos plurales: antropología de y desde los cuerpos. Buenos Aires: Biblos, 2011. P. 105-126. 
LANDER, Edgardo. Ciencias sociales: saberes coloniales y eurocéntricos. In: LANDER, Edgardo (comp.). La colonialidad del saber: eurocentrismo y ciencias sociales. Perspectivas latinoamericanas. Buenos Aires: CLACSO, 2005. P. 11 40.

LATOUR, Bruno. Facing Gaia. Cambridge: Polity, 2017.

LEPECKI, André. Introduction: Presence and body in Dance and performance Theory. In: LEPECKI, André (ed.). Of the presence of the body: essays on Dance and Performance Theory. Middletown: Wasleyan University Press, 2005. P. 1-9.

LIGIERO, Zeca. Performance e Antropologia de Richard Schechner. Rio de Janeiro: Mauad, 2012.

MACEDO, Valeria. De encontros nos corpos guarani. Ilha, São Paulo, v. 15, n. 2, p. 181-210, 2013.

MONCAYO, Victor Manuel. Presentación. Fals Borda: hombre hicotea y sentipensante. In: FALS BORDA, Orlando. Una sociología sentipensante para América Latina: acción colectiva e identidades indígenas, obreras y populares en Bolivia. Buenos Aires: CLACSO, 2009. P. 9-23.

NOGUEIRA, Renato. Denegrindo a filosofia: o pensamento como coreografia de conceitos afroperspectivistas. Griot, Amargosa, v. 4, n. 2, p. 1-19, 2011.

NOGUEIRA, Renato. Ubuntu como modo de existir: Elementos gerais para uma ética afroperspectivista. Revista da ABPN, Guarulhos, v. 3, n. 6, p. 147-150, 2012.

PERETTA, Éden. O soldado nu: raízes da dança buto. São Paulo: Perspectiva, 2015.

QUIGNARD, Pascal. El origen de la danza. Buenos Aires: Interzona, 2017.

QUINTERO RIVERA, Ángel G. Cuerpo y cultura: las músicas "mulatas” y la subversión del baile. Madrid: Iberoamericana. Vervuert, 2009.

RABELO, Miriam. A Possessão como prática: esboço de uma reflexão fenomenológica. Mana, Rio de Janeiro, v. 14, n. 1, p. 81-117, 2008.

RIBEIRO, Djamila. O que é lugar de fala?. Belo Horizonte: Letramento editora, 2017.

RIVERA CUSICANQUI, Silvia. Oprimidos pero no vencidos: luchas del campesinado aymara y qhechwa. 1900-1984. La Paz: La mirada salvaje, 2010. 
RIVERA CUSICANQUI, Silvia. Sociología de la Imagen: miradas ch'ixi desde la historia andina. Buenos Aires: Tinta Limón, 2015.

RODRIGUES, Graziela. Bailarino Pesquisador Intérprete: processo de formação. Rio de Janeiro: Funarte, 2005.

RODRÍGUEZ, Manuela. Entre ritual y espectáculo, reflexividad corporizada en el candombe. Avá - Revista de Antropología, Posadas, p. 145-161, 2009.

ROELNIK, Suely. Subjetividad e historia. In: GUATTARI, Félix; ROELNIK, Suely. Micropolítica: cartografías del deseo. Buenos Aires: Tinta Limón, 2013. P. 37-141.

SCHECHNER, Richard. Performance: teoría y prácticas interculturales. Buenos Aires: Libros del Rojas, Universidad de Buenos Aires, 2000.

SCHEPER HUGHES, Nancy; LOCK, Margareth. The mindful body. A prolegomenon to Futur Work in Medical Anthropology. Medical Anthropology Quarterly, Malden, v. 1, n. 1, p. 6-41, 1987.

SOUSA SANTOS, Boaventura. Descolonizar el saber, reinventar el poder. Montevideo: Ediciones Trilce, 2010.

STENGERS, Isabelle. Reativar o animismo. Cadernos de Leitura, Belo Horizonte, v. 62, p. 1-15, 2017.

TAYLOR, Diana. Introducción. ¿Qué son los estudios de performance? In: TAYLOR, Diana; STEUERNAGEL, Marcos (ed.). ¿Qué son los estudios de performance? Durham: Duke University Press, 2015. Disponible en: <https://scalar.usc.edu/nehvectors/wips/qu-son-los-estudios-de-la-performance>. Acceso el: 3 de abril de 2021.

TAYLOR, Nik; Tania SIGNAL. Theorizing Animals: re-thinking humanimal relations. Boston: Leiden, 2011.

TURNER, Victor. From Ritual to Theatre: The Human Seriousness of Play. New York: Paj Publications, 1982.

TURNER, Victor. The Anthropology of Performance. New York: PAJP, 1992.

UNO, Kuniichi. Hijikata Tatsumi: pensar um corpo esgotado. São Paulo: N-1 Edições, 2018.

VIVEIROS DE CASTRO, Eduardo. O nativo relativo. Mana, Rio de Janeiro, v. 8, n. 1, p. 113-148, abr. 2002.

WACQUANT, Loic. Corpo e alma: notas de aprendiz de boxe. Rio de Janeiro: Relume Dumará, 2002. 
WILLIAMS, Raymond. Marxismo y Literatura. Barcelona: Península, 1988.

Lucrecia Raquel Greco holds a PhD in Anthropological Sciences from Universidad de Buenos Aires. She is a visiting professor at Universidade Federal da Bahia (UFBA). She specializes in the anthropology of the body and performance as well as collaborative research. She has worked in social projects dedicated to the practice of performance in Brazil and Argentina among grassroots sectors and with indigenous peoples, and is currently studying motherhood. She has a background in performance and corporal work (mainly agama fo, Butoh, yoga and tango and theater of the oppressed).

ORCID: http://orcid.org/0000-0002-7943-114X

E-mail: lucregre@yahoo.com.ar

This original paper, translated by Tony O'Sullivan, is also published in Portuguese in this issue of the journal.

Received on March 22, 2020

Accepted on February 04, 2021

Editor-in-charge: Ana Sabrina Mora

This is an open-access article distributed under the terms of the Creative Commons Attribution License 4.0 International. Available at: <http://creativecom mons.org/licenses/by/4.0>. 